\title{
Additional ACRL Programs at San Francisco
}

\section{LIBRARY INSTRUCTION}

The ACRL Undergraduate Librarians Discussion Group will meet this year on Wednesday, July 2, 10:00 a.m.-12:00 noon. The topic for discussion will be Library Instruction and the UGL. Persons working in or interested in undergraduate libraries are invited to attend. For further information, contact Allan J. Dyson, Moffitt Undergraduate Library, University of California, Berkeley, CA 94720.

\section{Resource-Sharing}

The Urban Universities Library Committee of the ACRL University Libraries Section will sponsor a program entitled INFOPASS: Open Sesame for Graduate Students, on Tuesday, July 1, 10:00 a.m.-12:00 noon. A panel, moderated by the chairman of the committee, David E. Pownall, director of library services, Hofstra University, will describe the sophisticated resource-sharing system developed by the Illinois Regional Library Council, will identify the necessary elements for planning and implementation, will discuss benefits which accrue to graduate students through this system, and will analyze the impact of the system on large metropolitan university libraries. Members of the panel include: Beth Hamilton, executive director, Illinois Regional Library Council; Susan C. Keller, coordinator, Library Council of Metropolitan Milwaukee; Eric Halvorson, student, Graduate Library School, University of Chicago; William C. Roselle, director of the library, University of Wisconsin-Milwaukee; and William B. Ernst, university librarian, University of Illinois at Chicago Circle.

\section{Slavic and East Eunopean Classification}

The ACRL Slavic and East European Section, chaired by Katherine Cveljo, College of Library Science, University of Kentucky, will present a panel discussion, on Tuesday, July 1, 4:30-6:00 p.m., on Slavic and East European Classification. Serving as members of the panel are: Tatjana Lorkovic, Slavic librarian, University of Iowa; Wasyl Veryha, catalog librarian, University of Toronto; and Stan Humenuk, head catalog librarian, Western Illinois University. Katherine Cveljo will moderate the panel.

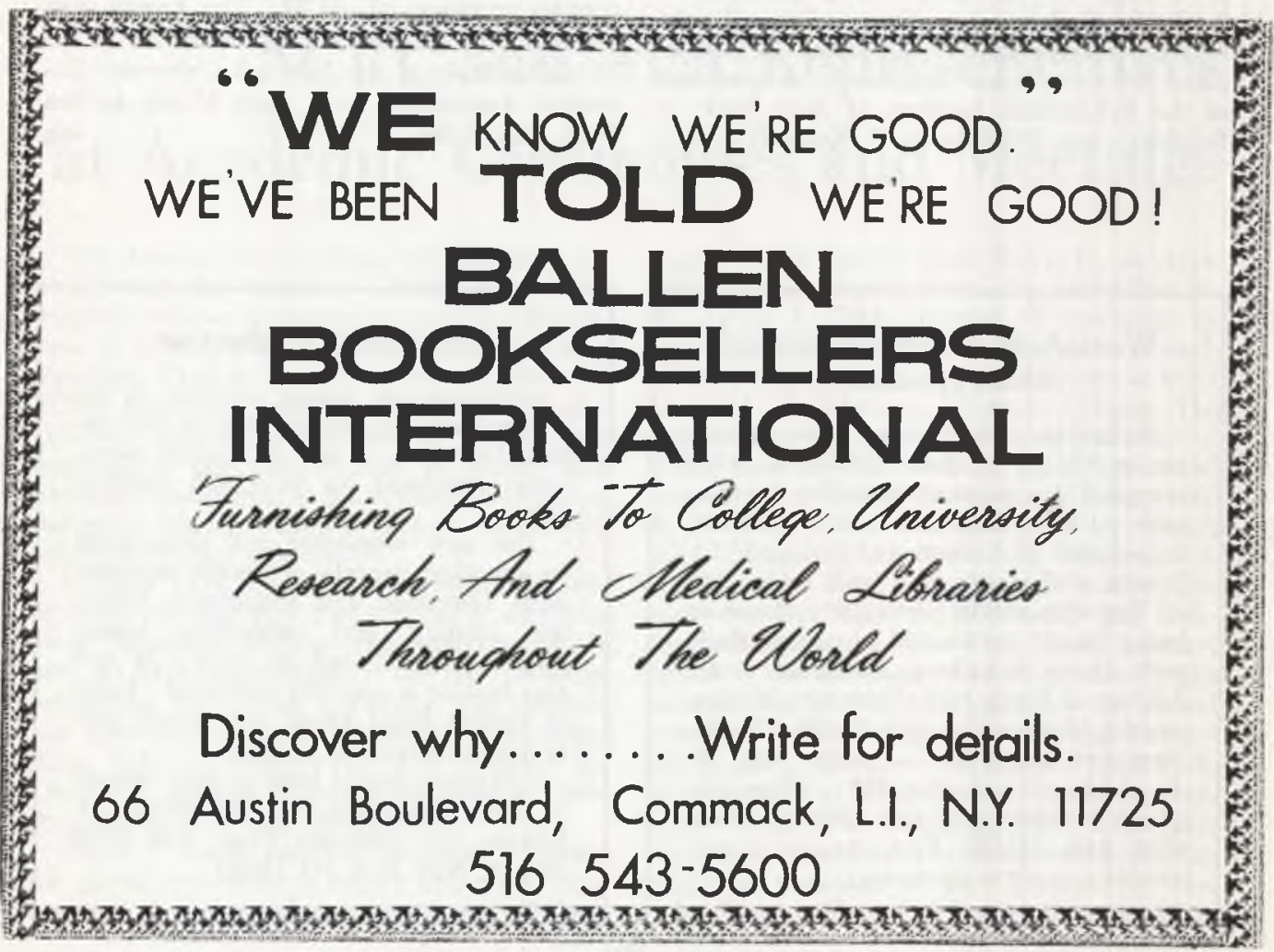

